The papers given at the congress will be published in the society's journal. The society also publishes a quarterly Bulletin, which contains a bibliography of current publications on the history of Nigeria and its neighbours.

\title{
New Discoveries at Ife
}

EARLY this year an important archaeological discovery was made at Ita Yemoo on the outskirts of Ife by a workman engaged in clearing a low mound to level a site for building. The bronzes were deeply patinated and appear to have lain undisturbed for a considerable period. They were taken to the Ife Museum for temporary exhibition before receiving laboratory treatment, and have now been exhibited at the British Museum and the Manchester University Museum. The finds include the standing figure of an Oni in full regalia, about nineteen inches high; a group of two figures, one of them probably a woman, arm-inarm and dressed in royal attire; two ceremonial staffs, probably used by the Ogboni society; two egg-shaped objects, each with two heads; and a small heavy brass object in the form of a drinking-cup, ornamented with a richly dressed royal female personage reclining on a stool. The site of the discovery, which has been purchased for Nigeria's Antiquities Department, has been excavated by Mr. Frank Willett of the Manchester Museum, and application has been made for the surrounding area to be declared a national monument until the full extent of the site is known.

\section{Discovery of Rock Paintings in Bauchi}

A NUMBER of cave paintings have been discovered recently in the Northern Region of Nigeria by the District Officer of Bauchi Division, Mr. H. Sassoon, at Geji, some twenty miles from Bauchi town. The paintings-about fifteen in all-are in a large open cave, five miles from the nearest track suitable for vehicles. There are two groups on the main wall of the cave, which is sheltered by trees; the deep red pigment has therefore been preserved, though some of it has been scraped away for ' magical ' purposes connected with fertility rites. The paintings are of large straight-horned African antelopes, monkeys, cows, and what appear to be human figures. A further outline is probably a horse, and if this is verified it may help to date the paintings at 800 to 850 years old. The first such find was at BirninKudu, Kano Province, in 1953, and consisted of cattle and some geometric designs.

\section{Margaret Wrong Memorial Fund: Award for 1957}

THE Margaret Wrong Prize for 1957 has been awarded to the Rev. J. J. R. Jolobe, for outstanding services to literature in South Africa. Mr. Jolobe has produced a great volume of writing in Xhosa and has done valuable work on the Xhosa Language Committee at Lovedale. 